\title{
Anti-inflammatory Effect of HaGF peptide of Harmonia axyridis
}

Dong-Hee Kim², Hyeon-Jeong Kim ${ }^{1,3}$, Jin-Young Lee, Jae-Sam Hwang ${ }^{5}$, In-Woo Kim ${ }^{4}$ Seul-Gi Lee', Hyeon-Guk Jeong ${ }^{1}$ and Bong-Jeun $\mathrm{An}^{1}{ }^{1}$

${ }^{1}$ Department of Cosmeceutical Science, Daegu Haany University, Gyeongsan 712-715, Korea

${ }^{2}$ Korea Promotion Institute for Traditional Medicine Industry, Gyeongsan 712-260, Korea

${ }^{3}$ Herbnoori, Daegu 702-062, Korea

${ }^{4}$ Department of Herbal Cosmetic Science, Hoseo University, Asan 336-795, Korea

${ }^{5}$ Department of Agricultural Biology, National Academy of Agricultural Science, Suwon 441-100, Korea

Received November 12, 2012 /Revised April 3, 2013 /Accepted April 22, 2013

\begin{abstract}
Harmania axyridis is known to display diverse biological activities, such as growth promotion. However, few studies have investigated the effect of $H$. axyridis on inflammation of the skin. In this study, we explored the anti-inflammatory effect of the Harmoniasin gene fragment (HaGF) peptide from $H$. axyridis on macrophage cells. During the entire experimental period, 5, 25, 50, and $100 \mu \mathrm{g} / \mathrm{ml}$ of HaGF showed no cytotoxicity. However, at these concentrations, HaGF inhibited the activity of iNOS and COX-2 by $51 \%$ and $49 \%$, respectively. In addition, the HaGF extract reduced the release of inflammatory cytokines, including TNF-a and IL-6. Therefore, HaGF has been LPS-induced macrophage Raw 264.7 cells could be expected from the inhibitory effects of the inflammatory.
\end{abstract}

Key words : Anti-inflammatory, COX-2, Harmonia axyridis, iNOS, lipopolysaccharide

\section{서 론}

예로부터 곤충은 동양에서 약용-식용으로 많이 이용되었는 데, 고서의 기록에 의하면 동의보감은 약 95 종의 약용 곤충이, 본초강목습유(本草綱目拾遺)에는 106 종의 약용 곤충이 기록 되어있다[22]. 이러한 곤충자원은 최근 생명공학 기술의 발달 과 함께 다양화 되고 있는데, 그 예로 각종 유용물질을 생산하 는 누에(실크, 누에가루, 동충하초), 꿀벌(꿀, 로얄제리. 프로폴 리스), 곤충의 외골격(chitin의 추출) 등이 좋은 예라 할 수 있 다. 또한 곤충의 추출물은 전통적인 생약으로 이용되었는데, 최근 이러한 곤충 추출물에 대한 효능 및 유효성분 분석에 대한 연구가 진행되고 있다. 이 외에도 곤충 자원은 유용생물 자원으로 현재 세계적으로 여러 분야에서 매우 광범위하게 개발 활용되고 있다[6, $7,8,12,16]$.

염증은 생체 혹은 조직에 물리적 자극이나 화학적 물질, 세 균 감염 등의 기질적 변화를 가져오는 침습이 가해질 때 그 손상부위를 수복 재생하려는 복구기전으로서 자극이 가해지 면 국소적으로 염증성 성분이 증가되면서 염증이 유발된다 [14]. 임상적으로는 발적, 발열, 종창, 동통, 기능장애 등의 증

\footnotetext{
*Corresponding author

Tel : +82-53-819-1429, Fax : +82-53-819-1429

E-mail : anbj@dhu.ac.kr

This is an Open-Access article distributed under the terms of the Creative Commons Attribution Non-Commercial License (http://creativecommons.org/licenses/by-nc/3.0) which permits unrestricted non-commercial use, distribution, and reproduction in any medium, provided the original work is properly cited
}

상이 나타난다[11]. 대식세포는 선천면역뿐만 아니라 획득면 역 등 다양한 숙주반응에 관여하여 항상성 유지에 관여하는 것으로 알려져 있으며, 염증반응 시에는 nitric oxide $(\mathrm{NO})$ 와 cytokine을 생산하여 감염초기에 생체방어에 중요한 역할을 한다[3]. 포유동물 세포의 nitric oxide synthase (NOS)의 경 우, 유사형태가 3가지 존재하는데 neuronal NOS (nNOS), endothelial NOS (eNOS), 그리고 inducible NOS (iNOS)이다. 그 중에서 특히 iNOS가 염증반응에 관여한다. $\mathrm{nNOS}$ 와 $\mathrm{eNOS}$ 는 항상 발현되어 있으며, iNOS의 경우 interferon- $\gamma$, lipopolysaccharide (LPS), 그리고 여러 가지 염증 cytokine의 자 극이 있을 때 발현된다. 또한 NO는 급성, 만성 염증반응을 조절하기도 한다. COX에 대해서는 1990년대 초반에 주로 연 구되었는데, 이 또한 유사형태가 두 가지 존재한다. COX-1은 거의 모든 조직에 발현되어 있고, prostagrandin을 생산하여 신장의 혈액흐름을 조절하거나 위장의 세포를 보호하는 등의 생리적인 기능을 조절한다. 반대로 COX-2의 경우는 미생물에 의한 감염이나 손상 혹은 여러 요인의 스트레스에 반응한 대 식세포 (macrophage)에서 발현된다. 즉 $\mathrm{iNOS}$ 와 COX-2의 발 현유무는 면역 세포의 염증 반응에 관여한다. 또한 염증 사이 토카인(proinflammatory cytokines)인 tumor necrosis factora (TNF-a), interleukin-1 $\beta$ (IL-1 $\beta)$, interleukin-6 (IL-6), monocyte chemoattractant protein-1 (MCP-1) 등이 염증 반응에 관 여하는 인자로 알려져 있다 $[9,24]$.

따라서 본 연구에서는 무당벌레 유충으로부터 분리된 펩타 이드 유전자 Harmoniasin의 일부 영역 HaGF을 이용하여 LPS 로 활성 된 Raw 264.7 cell로 염증에 관련된 다양한 기전과 
단백질 발현을 측정하였다.

\section{재료 및 방법}

\section{재료}

본 실험에서 사용한 펩타이드 HaGF는 AnyGen (Gwang-ju, Korea)사에서 $98 \%$ 이상의 순도로 합성하였고, $0.01 \%$ acetic acid에 녹여 사용하였다

\section{시약 및 기기}

세포 배양액인 dulbeco's modifide eagle medium (DMEM), fetal bovine serum (FBS), streptomycin penicillin 등의 세포배양용 시약들은 invitrogen (Carlsbad, CA, USA)사 에서 구입하였다. 실험에 사용된 시약 중 sodium dodesyl sulfate (SDS), acrylamide, bisacrylamide는 Bio-rad사 (Hercules, CA, USA)에서 구입하였고, NP-40, protease inhibitor, RIPA buffer, griess reagent 등은 Sigma Chemical Co. (St. Louis, $\mathrm{MO}, \mathrm{USA}$ )에서 구입하였다. 실험에 사용된 1차 항체인 $\mathrm{iNOS}$ 는 BD bioscience (Sanjose, CA, USA)에서 구입하였으며, COX-2는 cayman (Ann arbor, MI, USA)에서 - $\beta$-actin과 2차 항체인 anti-rabbit $\mathrm{Ig}-\mathrm{G}$ horseradish peroxidase (HRP)-conjugated antibody는 Santa cruz사 (CA, USA)에서 구입하였다. $\mathrm{PGE}_{2}$ 측정을 위한 ELISA kit는 R\&D systems Inc (Minneapolis, MN, USA)에서 구입하여 실험에 사용하였다.

\section{세포 배양}

마우스의 대식세포주인 Raw 264.7 cell은 한국세포주은행 (KCLB)에서 분양 받아 $10 \% \mathrm{FBS}$ 과 $1 \%$ penicillin-streptomycin 을 포함하는 $\mathrm{DMEM}$ 배지를 사용하여 $37^{\circ} \mathrm{C}, 5 \% \mathrm{CO}_{2}$ 조건에서 배양하였다.

\section{MTT assay에 의한 세포 생존율 측정}

세포 생존율을 측정하기 위하여 MTT 실험 방법을 이용하 였다. Raw 264.7 cell $5 \times 10^{4}$ cells $/ \mathrm{ml}$ 의 농도로 96- well plate에 분주하고, $37^{\circ} \mathrm{C}, 5 \% \mathrm{CO}_{2}$ incubator에서 24 시간 배양 후 $\mathrm{HaGF}$ 를 $5,10,25,50,100,500 \mu \mathrm{g} / \mathrm{ml}$ 농도로 24 시간 동안 처리하였 다. Well당 $20 \mu 1$ 의 MTT용액을 첨가하여 $37^{\circ} \mathrm{C}, 5 \% \mathrm{CO}_{2}$ incubator에서 4 시간 동안 반응시킨 후 MTT solution을 제거하 고 각 well에 DMSO $200 \mu 1$ 을 첨가하여 생성된 formazan 결정 을 용해시켰다. 용해 시킨 후 microplate reader를 이용하여 $540 \mathrm{~nm}$ 에서 측정하여 세포생존율을 백분율로 표시하였다.

\section{Nitric Oxide 생성량 측정}

$\mathrm{NO}$ 의 농도는 배양액 내의 nitrite 농도를 griess reagent를 이용하여 측정하였다. Raw 264.7 cell은 DMEM 배지를 이용 하여 $5 \times 10^{5}$ cells $/ \mathrm{ml}$ 로 6 well plate 조절해 분주 하였다. $5 \%$
$\mathrm{CO}_{2}$ incubator에서 24시간 배양한 후 세포에 $1 \mathrm{\mu g} / \mathrm{ml}$ 의 LPS 를 처리하고 1 시간 뒤에 $5,10,25,50,100 \mu \mathrm{g} / \mathrm{ml}$ 농도로 $\mathrm{HaGF}$ 을 처리하여 24시간 배양하였다. 배양액의 상층액을 얻은 후 griess 시약과 반응 시킨 후 ELISA reader로 $540 \mathrm{~nm}$ 에서 흡광 도를 측정하여 $\mathrm{NO}$ 생성율을 백분율로 표시하였다

Western blot을 이용한 inducible NO synthase (iNOS), cyclooxygenase-2 (COX-2) 활성 측정

iNOS protein 활성 측정을 확인하기 위하여 대식세포주인 Raw 264.7 cell은 DMEM 배지를 이용하여 $5 \times 10^{5}$ cells $/ \mathrm{ml}$ 로 조절한 후 $100 \mathrm{~mm}$ cell culture dish에 접종하고, $5 \% \mathrm{CO}_{2}$ incubator에서 24시간 전 배양하였다. 세포에 $1 \mu \mathrm{g} / \mathrm{ml}$ 의 LPS를 처리하고 1 시간 뒤에 $5,25,50,100 \mu \mathrm{g} / \mathrm{ml}$ 의 HaGF를 처리하 여 24시간 배양 한 후 배지를 제거하고 phosphate buffered saline (PBS)로 2번 세척해 준 후, lysis buffer를 이용하여 단백 질을 추출한 후 원심 분리하여 상등액을 취하였다. 상등액을 bradford assay로 단백질 농도를 정량 한 후 $10 \%$ SDS-PAGE 를 시행하고, 전개된 단백질을 nitrocellulose membrane으로 transfer시켰다. 이 membrane을 5\% skim milk로 1시간 동안 blocking하고, 1 차 항체를 희석 $(1: 1,000)$ 하여 $4^{\circ} \mathrm{C}$ 에서 over night 한 다음, $\mathrm{TBST}$ 로 10 분 간격으로 3 회 세척하고, 각각의 2 차 항체를 $1: 1,000$ 으로 희석하여 실온에서 2시간 동안 상온에 서 반응시켰다. 다시 TBST로 10 분간 3회 세척 후 $\mathrm{ECL}$ 용액으 로 반응시켜 LAS 4000 chemiluinescence detection system (Fuji, Tokyo, Japan)을 이용하여 현상 및 정량을 하였다.

\section{TNF- $a, I L-6, I L-1 \beta$ 생성량 측정}

세포배양액 내의 TNF-a, IL-6, IL-1 $\beta$ 생성량은 ELISA kit를 이용하여 측정하였다. Raw 264.7 cell은 DMEM 배지를 이용 하여 $5 \times 10^{5}$ cells $/ \mathrm{ml}$ 로 조절한 후 6 well plate에 접종하고, $5 \%$ $\mathrm{CO}_{2}$ incubator에서 24시간 배양하였다. 세포에 $1 \mathrm{\mu g} / \mathrm{ml}$ 의 LPS를 처리 한 뒤 1 시간 후에 $5,25,50,100 \mu \mathrm{g} / \mathrm{ml}$ 농도로 $\mathrm{HaGF}$ 를 처리하여 24 시간 배양하였다. 배양배지를 취하여 TNF-a, IL-13, IL-6를 측정하였다.

\section{통계처리}

모든 실험은 3 회 반복하여 측정하였고, 그 결과는 평균값 \pm 표준편차로 나타냈으며 통계적 분석은 SPSS 10.0 프로그램 을 이용하여 각 처리군 간의 유의성 $(p<0.05,0.01)$ 검증을 위해 분산분석(analysis of variance, ANOVA) 후 tukey test로 다중 비교를 실시하였다.

\section{결과 및 고찰}

Raw 264.7 cell에 대한 독성

마우스 대식세포인 Raw 264.7 cell에 대한 $\mathrm{HaGF}$ 의 세포독 
성을 확인하기 위하여 MTT assay를 수행하였다. HaGF를 농 도 별로 24 시간 동안 처리한 결과 $100 \mathrm{\mu g} / \mathrm{ml}$ 의 농도까지는 독성이 나타나지 않았지만, $500 \mu \mathrm{g} / \mathrm{ml}$ 의 농도에서는 세포의 생존율을 $95 \%$ 감소시켰다(Fig. 1). HaGF는 $100 \mathrm{\mu g} / \mathrm{ml}$ 이하의 농도에서는 세포독성이 낮아 세포의 생존율에 영향을 주지 않는다는 사실을 확인할 수 있었다.

\section{Nitric oxide (NO) 생성억제 효과}

$\mathrm{NO}$ 는 박테리아를 죽이거나 종양을 제거시키는 역할을 하 지만, 병리적 원인에 의해 과도하게 생성, 분비되면 염증을 유발시키게 되며, 조직 손상, 유전자 변이 및 신경손상 등을 일으키는 것으로 알려져 있다[13, 20]. 또한, $\mathrm{NO}$ 는 $\mathrm{NO}$ 합성효 소에 의해 1-arginine으로부터 생성되는 무기 유리체로 면역반 응, 세포독성, 신경 전달계 및 혈관이완 등 여러 가지 생물학적 인 과정에 관여하는 것으로 알려져 있으며, 농도에 따라 세포 기능유지에 중요한 작용을 하기도 하고 세포독성을 일으키기 도 한다[14, 17]. NO는 그 자체로 염증유발과 조직손상을 일으 킬 뿐만 아니라, 활성산소인 superoxide와 결합하게 되면 보다 반응성이 강한 peroxynitrite의 형태로 전환되어 생체조직의 괴사를 야기할 수 있다[19]. 이에 본 실험에서는 NO 생성에 대한 $\mathrm{HaGF}$ 의 효과를 알아보았다. 생성된 $\mathrm{NO}$ 양을 griess 시약 을 이용하여 세포배양액 중에 존재하는 $\mathrm{NO}_{2}^{-}$의 형태로 측정하 여 Fig. 2에 나타내었다. 그 결과 LPS 처리 후 NO 생성량은 정상세포에 비하여 약 4배 이상 증가되었다. HaGF를 $100 \mu \mathrm{g} /$ $\mathrm{ml}$ 의 농도로 처리한 군에서는 LPS로 증가된 $\mathrm{NO}$ 생성량이 LPS 처리군에 비하여 $50 \%$ 이상 감소함을 확인할 수 있었다.

\section{TNF- $a, I L-1 \beta, I L-6$ 생성 억제 효과}

TNF- $a$ 를 포함한 매개물질인 cytokine IL-6와 IL-1 $\beta$ 는 NF- $\mathrm{K}$

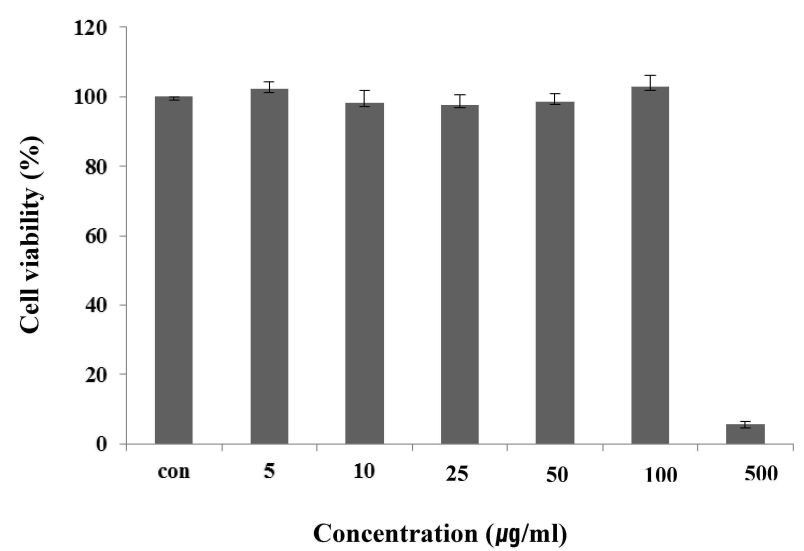

Fig. 1. Cell viability of HaGF on Raw 264.7 cell. Raw 264.7 cells were treated with $5,10,25,50,100,500 \mathrm{\mu g} / \mathrm{ml}$ of HaGF dissolved in media for $1 \mathrm{hr}$ prior to the addition of LPS $(1 \mathrm{\mu g} / \mathrm{ml})$, and the cells were further incubated for 24 hr. Data represent the mean \pm S.D. with eight separate experiments.
$\mathrm{B}$ 를 통해 활성화 되고 또한 NF- $\mathrm{kB}$ 를 활성화 시켜서 cytokine cascade를 증폭하고 염증상태를 확장한다[2]. 특히, TNF- $a$ 는 염증반응에 있어서 중요한 역할을 하며 macrophage와 mast cell 등에서 분비되며, LPS반응의 주요 매개체로서 내재면역 에 있어서도 중요한 역할을 하며 만성 염증 반응과도 관련되 어 있다[10]. IL-1ß는 T-cell의 활성화, B-cell의 성숙, NK cell의 activity를 활성화 하며, IL-6는 림프구를 활성화시켜 항체생산 을 증가시키는 것으로, IL-6의 level은 염증 반응에서 항상 증 가하는 것으로 보고되고 있다[1]. 본 실험에서 LPS는 TNF-a, $\mathrm{IL}-1 \beta$, IL-6의 생성을 증가 시켰지만, $\mathrm{HaGF}$ 를 농도 별로 처리 한 군에서는 억제되는 것을 확인할 수 있었다(Fig. 3).

\section{iNOS, COX-2의 단백질 발현 저해 효과}

iNOS는 평소에는 세포 내에 존재하지 않으나 일단 유도되 면 장시간 동안 다량의 $\mathrm{NO}$ 를 생성하며, 생성된 $\mathrm{NO}$ 는 혈관 투과성, 부종 등의 염증 반응을 촉진 시킬 뿐만 아니라 염증매 개체의 생합성을 촉진하여 염증을 심화시키는 것으로 알려져 있다 $[5,21]$. 염증반응과 관련된 조직 손상에서 $\mathrm{NO}$ 와 $\mathrm{iNOS}$ 의 발현이 증가되어 있음이 보고된 바 있다 $[15,18,23]$ COX-2는 cyclooxygenase와 peroxidase 활성을 모두 가지고 있는 효소 이다. Cyclooxygenase 기능으로서 arachidonic acid를 prostagland로 변환하고, peroxidase 기능으로서는 endoperoxide 를 prostaglandin로 변환시키며, prostaglanin는 prostaglandins, thromboxane 및 prostacyclins의 전구체로 사용된 다. COX-1은 모든 세포에 존재하면서, 정상세포의 항상성을 유지하며, COX-2는 급성염증반응에서 prostaglandin의 합성 에 관여하고, LPS 및 cytokine에 의해 발현이 유도된다 $[4,9]$

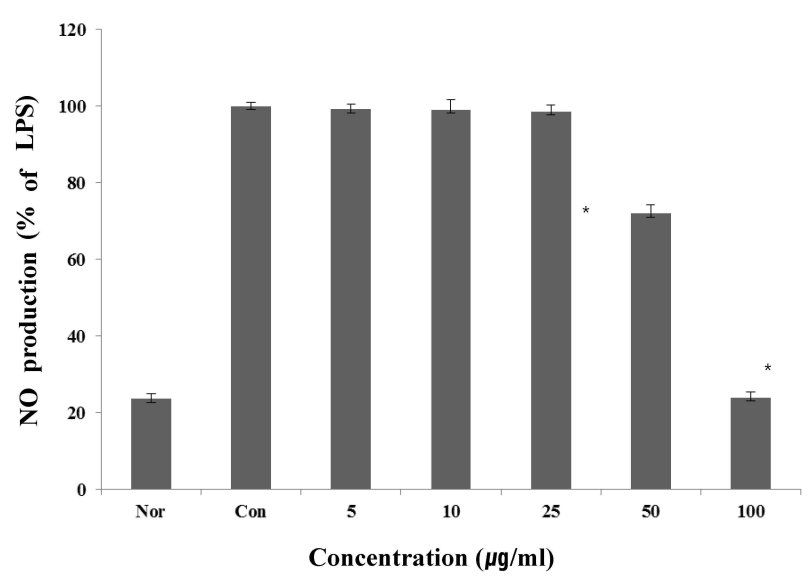

Fig. 2. Inhibitory effects of HaGF on the production of nitric oxide Raw 264.7 cells. Raw 264.7 cells were cultured with LPS $(1 \mu \mathrm{g} / \mathrm{ml})$ in the presence or absence of HaGF for $24 \mathrm{hr}$ to determine the level of NO. (Nor: LPS not induced group, Con: LPS induced group) The data represent the mean $\pm S D$ of three separate experiments (significant as compared to control ${ }^{*} p<0.05$ ). 

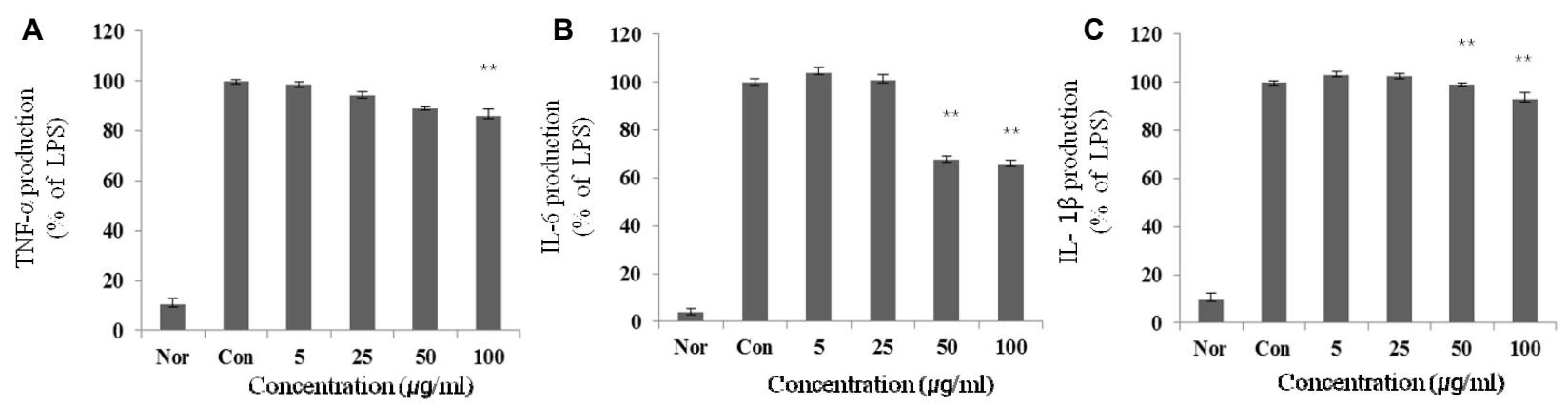

Fig. 3. Effect of HaGF on the production of cytokines stimulated by LPS. Production of TNF-a (a), IL-6 (b), IL-1ß (c) were measured in the medium of Raw 264.7 cells cultured with LPS $(1 \mathrm{\mu g} / \mathrm{ml})$ in the presence or absence of HaGF for $24 \mathrm{hr}$. The amount of TNF-a was measured by immunoassay as described in materials and methods. (Nor : LPS not induced group, Con: LPS induced group) Data represent the mean \pm S.D. with three separate experiments. One-way ANOVA was used for comparisons of multiple group means followed by t-test (significant as compared to control ${ }^{*} p<0.05,{ }^{* *} p<0.01$ ).
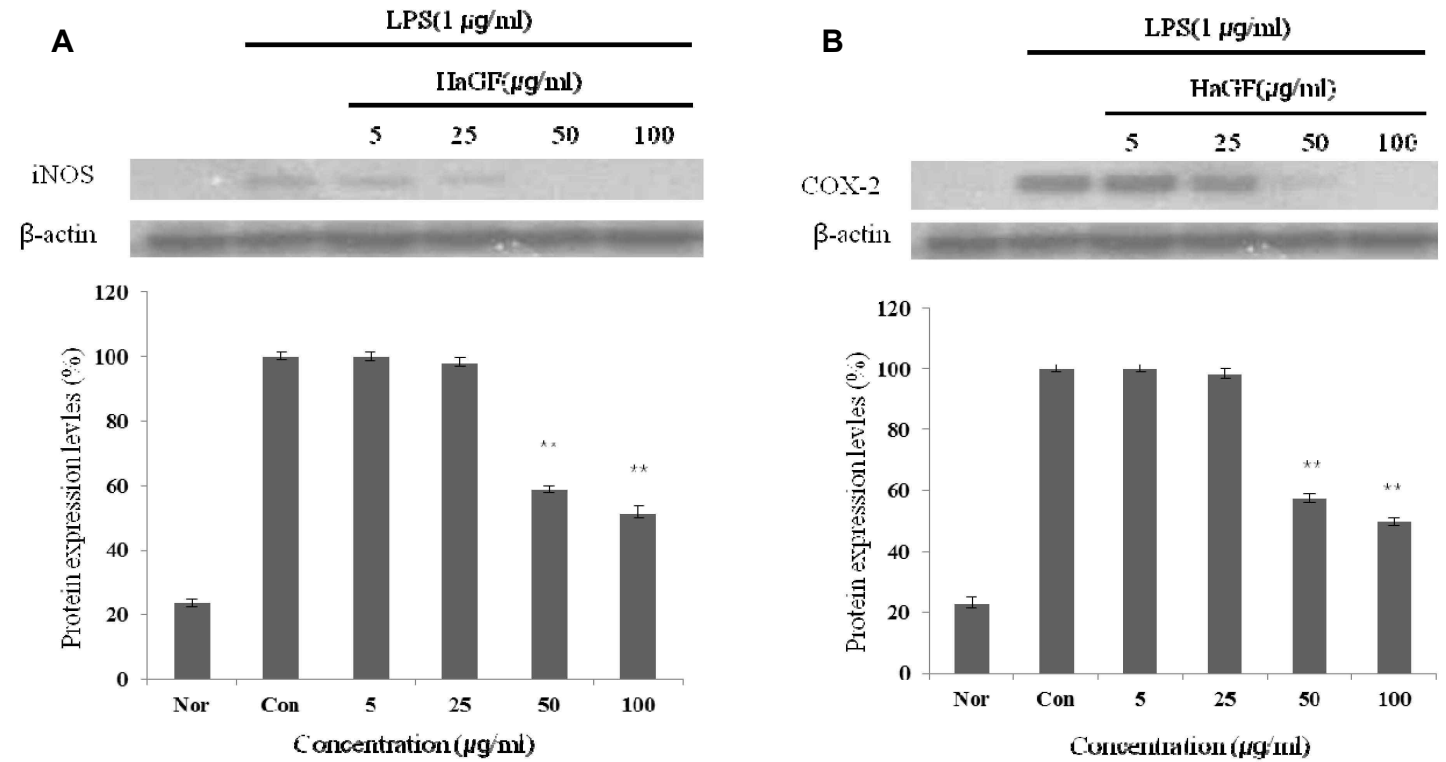

Fig. 4. Inhibitory effects of HaGF on the protein levels of iNOS and COX-2 in Raw 264.7 cells. Raw 264.7 cells $\left(5 \times 10^{5}\right.$ cells $\left./ \mathrm{ml}\right)$ were pre-incubated for $24 \mathrm{hr}$, and the cells were stimulated with lipopolysaccharide $(1 \mathrm{\mu g} / \mathrm{ml})$ in the presence of complex extracts sample $(5,25,50,100 \mu \mathrm{g} / \mathrm{ml})$ for $24 \mathrm{hr}$. (Nor: LPS not induced group, Con: LPS induced group) Data represent the mean \pm S.D. with three separate experiments. One-way ANOVA was used for comparisons of multiple group means followed by t-test (significant as compared to control ${ }^{*} p<0.05,{ }^{* *} p<0.01$ ).

따라서, 본 연구에서는 $\mathrm{HaGF}$ 에 의한 $\mathrm{NO}$ 생성 저해 기전을 확인하기 위해 western blot을 실시하여 iNOS와 COX-2 단 백질 발현을 측정 하였다. 그 결과 LPS에 의해 증가된 iNOS 와 COX-2의 단백질 발현양이 농도 의존적으로 유의성 있게 감소되었다. $\beta$-Actin의 band density 비율에 따라 iNOS 단 백질 생성을 $49 \%$ 와 COX-2의 단백질 발현을 $51 \%$ 저해함을 확인 하였다(Fig. 4). 이를 통해 LPS 자극에 의해 발현된 $\mathrm{iNOS}$ 와 COX-2는 많은 양의 $\mathrm{NO}$ 를 생성하게 되며 $\mathrm{HaGF}$ 는 이를 저해함으로서 결과적으로 NO 생성을 억제함을 확인할 수 있었다.

\section{감사의 글}

본 논문은 농촌진흥청 차세대 바이오그린21사업(과제번호: PJ008158)의 지원에 의해 이루어진 것임.

\section{References}

1. Delgado, A. V., McManus, A. T. and Chambers, J. P. 2003. Production of tumor necrosis factor-alpha, interleukin 1-beta, interleukin 2, and interleukin 6 by rat leukocyte subpopulations after exposure to substance. P Neuro 37, 355-361. 
2. Hanada, T. and Yoshimura, A. 2002. Regulation of cytokine signaling and inflammation. Cytokine Growth Factor Rev 13, 412-421.

3. Higuchi, M., Hisgahi, N., Taki, H. and Osawa, T. 1990. Cytolytic mechanisms of activated macrophages. Tumor necrosis factor and L-arginine-dependent mechanisms act synergistically as the major cytolytic mechanisms of activated macrophages. J Immunol 144, 1425-1431.

4. Hume, D. A., Wells, C. A. and Ravasi, T. 2007. Transcriptional regulatory networks in macrophages. Novartis Found Symp 281, 2-18.

5. Kim, R. G., Shin, K. M., Chun, S. K., Ji, S. Y., Seo, S. H., Park, H. J., Choi, J. W. and Lee, K. T. 2002. In vitro anti-inflammatory activity of the essential oil from ligularia fischeri var. spiciformis in murine macrophage RAW 264.7 cells. Yakhak Hogi 46, 343-347.

6. Kou, J., Ni, Y., Li, N., Wang, J., Liu, L. and Jiang, Z. H. 2005. Analgesic and anti-inflammatory activities of total extract and individual fractions of Chinese medicinal ants Polyachis lamellidens. Biol Pharm Bull 28, 176-180.

7. Kurioka, A. and Uamazaki, M. 2002. Purification and identification of flavonoids from the yellow green cocoon shell (Sasamayu) of the silkworm, Bombys mori. Biosci Biotechnol Biochem 66, 1396-1399.

8. Li, N. G., Osakovskii, V. L. and Ivanova, S. S. 2003. Chemical composition and cryoprotective activity of ethanol extract from winter caterpillars Aporia crataegi L. IzV Akad Nauk Ser Biol 5, 547-552.

9. Lin, W. J. and Yeh, W. C. 2005. Implication of Toll-like receptor and tumor necrosis factor alpha signaling in septic shock. Shock 24, 206-209.

10. Lee, A. K., Sung, S. H., Kim, Y. C. and Kim, S. G. 2003. Inhibition of lipopolysaccharide -inducible nitric oxide synthase, TNF- $a$ and COX-2 expression by sauchinone effects on $\mathrm{I}-\kappa \mathrm{Ba}$ phosphorylation, $\mathrm{C} / \mathrm{EBP}$ and $\mathrm{AP}-1$ activation. British J Pharmacol 139, 11-20.

11. Lee, T. H., Kwak, H. B., Kim, H. H., Lee, Z. H., Chung, D. K., Baek, N. i. and Kim, J. 2007. Methanol extracts of Stewartia Korean inhibition cyclooxygenase-2 (COX-2) and inducible nitric oxide synthase (iNOS) gene expression by blocking NF-Kappa B transactivation in LPS-activated Raw 264.7 cells. Mol Cells 23, 398-404.

12. Ma, Y., Wang, X., Zhao, Y., Kawabata, T. and Okada, S. 1997. Inhibitory effects of Chinese and extract (CAE) on nephrotoxycity induced by ferric-nitrilotriacetate (Fe-NTA) in Wistar rats. Res. Commun Mol Pathol Pharmacol 96, 169-178.

13. Marin, J. and Rodriquez-Martinez, M. A. 1997. Role of vascular nitric oxide in physiological and pathological conditions. Pharmacol Ther 75, 111-134.

14. Moncada, S., Palmer, R. M. and Higgs, E. A. 1991. Nitric oxide: physiology, pathophysiology and pharmacology. Pharmacol Rev 43, 109-142.

15. Mori, M. 2007. Regulation of nitric oxide synthesis and apoptosis by arginase and arginine recycling. J Nutr 137, 1616-1620.

16. Nakatani, T., Konishi, T., Miyahara, K. and Noda, N. 2004. Three novel cantharidin-related compounds from the Chinese blister beetle, Mylabris Phalerata Pall. Chem Pharm Bull 52, 807-809.

17. Nathan, C. and Xie, Q. W. 1994. Nitric oxide synthases: roles, tolls and controls. Cell 78, 915-918.

18. Palmer, R. M., Ashton, D. S. and Moncada, S. 1988. Vascular endothelial cells synthesize nitric oxide from L-arginine. Nature 333, 664-666.

19. Radi, R., Beckman, J. S., Bush, K. M. and Freema, B. A. 1991. Peroxynitrite oxidation of sulfhydryls the cytotoxic potential of superoxide and nitric oxide. J Biol Chem 266, 4244-4250.

20. Rodeberg, D. A., Chaet, M. S., Bass, R. C., Arkoviz, M. S. and Garcia, V. F. 1995. Nitric oxide: An overview. American J Surgery 170, 292-303.

21. Tezuka, Y., Irikawa, S., Kaneko, T., Banskota, A. H., Nagaoka, T., Xiong, Q., Hase, K. and Kadota, S. 2001. Screening of Chinese herbal drug extracts for inhibitory activity on nitric oxide production and identification of an active compound of zanthoxylum bugeanum I Ethnopharmacol 77, 209-217.

22. Wang, C. and Leger, R. J. 2005. Developmental and transcriptional responses to host and nonhost cuticles by the specific locust pathogen Metarhizium anisoplae var. acridum. Eukaryot Cell 4, 937-947.

23. Weisz, A., Cicatiello, L. and Esumi, H. 1996. Regulation of the mouse inducible-type nitric oxide synthase gene promoter by interferon- $\gamma$, bacterial lipopolysaccharide and NG-monomethyl-L-arginine. Biochem J 316, 209-215.

24. Yun, H. J., Heo, S. K., Yi, H. S., Kim, C. H., Kim, B. W. and Park, S. D. 2008. Anti-inflammatory effect of injinho-tang in RAW264.7 Cells. Korean J Herbol 23, 169-178. 
초록 : 무당벌레에서 유래된 HaGF peptide를 이용한 염증 억제 효과

김동희 ${ }^{2} \cdot$ 김현정 ${ }^{13} \cdot$ 이진영 ${ }^{4} \cdot$ 황재삼 ${ }^{5} \cdot$ 김인우 $^{5} \cdot$ 이슬기 ${ }^{1} \cdot$ 정현국 $^{1} \cdot$ 안봉전 $^{1} \star$

$\left({ }^{1}\right.$ 대구한의대학교 화장품약리학과, ${ }^{2}$ 한국한방산업진흥원, ${ }^{3}$ 허브누리, ${ }^{4}$ 호서대학교 한방화장품과학과,

${ }^{5}$ 국립농업과학원 농업생물부)

본 연구에서는 무당벌레 유충으로부터 분리된 항균 펩타이드 유전자의 일부 영역인 $\mathrm{HaGF}$ 를 이용하여 대식세 포의 염증에 미치는 영향을 조사하였다. 세포는 LPS 처리 후 한 시간 뒤에 HaGF를 처리를 하여, 세포 독성이 나타나지 않는 농도인 5, 25,50,100 $\mathrm{mg} / \mathrm{ml}$ 을 사용하였다. 그 결과 HaGF가 염증성 cytokine의 생성을 감소시키 는 것을 확인 하였으며 iNOS와 COX-2 역시 $100 \mu \mathrm{g} / \mathrm{ml}$ 의 농도에서 각각 $51 \%, 49 \%$ 저해율을 보였다. 따라서, $\mathrm{HaGF}$ 는 LPS로 유도된 대식세포주인 Raw 264.7 세포에서의 염증 반응 억제 효과를 기대할 수 있었다. 